\title{
POLITICAL POLARIZATION AND ITS CONSEQUENCES ON DEMOCRATIC ACCOUNTABILITY
}

\author{
ANDRÁS KÖRÖSÉNYI ${ }^{1}$
}

\begin{abstract}
This paper first explores the polarization thesis, according to which between 1990-2010 political polarization increased to a large extent in the Hungarian political elite and among citizens, although it did not undermine the stability of the political system. Second, it gives an endogenous explanation for this phenomenon. Third, through theoretical discussion and empirical examples taken from Hungarian politics it is revealed that although growing polarization has not generated regime instability, it reduces, or might reduce, the efficiency of the operation of democracy. Five mechanisms of the effects of ideological polarization which weaken democratic accountability are explored.
\end{abstract}

KEYWORDS accountability, democratic elitism, political polarization, Hungarian politics

Joseph Schumpeter, the founder of the elitist theory of democracy, defined democracy as follows:

“... the democratic method is that institutional arrangement for arriving at political decisions in which individuals acquire the power to decide by means of a competitive struggle for the people's vote." (1987: 269)

It is less well known that Schumpeter argued that the proper functioning of democracy defined this way depends on several preconditions. One of these is democratic restraint, according to which democratic governance can only be succesful if all participants accept the structural principles of society. That is, the success of democracy demands consensus around these principles. According to Schumpeter:

1 Institute for Political Science, Centre for Social Sciences, Hungarian Academy of Sciences 1014 Budapest, Országház utca 30.korosenyi.andras@tk.mta.hu 
"Whenever these principles are called into question and issues arise that rend a nation into two hostile camps, democracy works at a disadvantage." (Emphasis added.) (1987:296)

The Schumpeterian tradition in political science taken in a narrow sense has diverged, but both main schools have taken seriously the question of consensus/dissensus. One school is the competitive theory of democracy which requires consensus among voters. According to the economic model of democratic competition put forward by Anthony Downs at the end of the 1950s in his book An Economic Theory of Democracy, if the preferences of the voters follow a normal distribution on a left-right scale, competing political parties will approach the centre. ${ }^{2}$ Whichever party wins the election, the centripetal tendency caused by the competition will result in consensusbased public policy. However, if the distribution of voter preferences is U-shaped, fewest voters will be found in the centre and the number of voters will increase towards the end of the scale and parties will manouvre towards the extreme left and right, producing a centrifugal trend. According to Downs, in a situtation like this, whoever wins the elections the result could be civil war.

The other main school is the political sociological theory of democratic elitism. In the new elite paradigm worked out by John Higley and his collaborators in the 1980s, attention was directed from competition to the social and political preconditions of the stability of liberal democracies (Field and Higley 1980; Higley and Burton 2006; Best and Higley 2010). Instead of competing political leaders, Higley and his colleagues focused on political elite groups and their relationships in a broader sense. They showed that the basis of the stability of a democratic regime is the forming of an underlying consensus among elites rather than among voters. While this consensus might not extend to values, it covers the norms which concern the operation of democratic institutions. If this consensus is not formed, or unravels, the stability of democracy is imperiled.

Higley and his colleagues reached their conclusions based on sociohistorical and comparative elite research. Through empirical studies they looked for historical ways and elite constellations that led to the establishment of stable liberal democracies. They found two predominant ways this could occur: negotiated elite settlement and gradually forming elite convergence. They also found that elite disunity leads to destabilization.

Following the democratic transitions of East-Central Europe between 1989-

2 For this correlation to be true, it requires two competing parties, and their being rational and office-oriented as preconditions in Downs' (1957) model. 
92 they broadened their research to include the region. The result was that the negotiated-agreement-based mode of transition witnessed there - which includes roundtable negotiations - fulfilled the criteria of elite settlement. According to the authors, this produced an elite consensus that stabilized the emerging liberal democracies (Higley-Burton 2006: 84-88; Higley-Lengyel 2000: 14-15). ${ }^{3}$ This finding corresponded to the understanding formed in the transitology literature of the 1990s which viewed the Polish and Hungarian roundtable negotiations as the celebrated means of democratic transition.

However, in the decade after the turn of the millennium more and more political observers and analysts indicated growing polarization in Polish and Hungarian politics. In sociology and political science many started to question the thesis of Higley and his colleagues; namely, that a negotiated transition inevitably leads to enduring elite consensus and political stability. Among Hungarian elite researchers, Gabriella Ilonszki and György Lengyel think that an ever-more confrontative style of politics and a permanent violation of norms on the part of the political elite in the decade after the turn of the millennium have turned Hungary into a "simulated democracy" (Ilonszki and Lengyel 2010). Based on the political developments of the past decade they hold that the agreements of 1989-90 produced not a durable elite consensus, but only a temporary compromise. ${ }^{5}$ Jacek Wasilewski (2010), meanwhile, reaches the conclusion by analyzing Polish politics that the consensus underlying democratic elitism unraveled after the turn of the millennium. Thomas Baylis (2012) in his comparative analysis of Central European countries points to the Hungarian and the Polish examples, where the establishment of an elite consensus was questionable from the beginning.

3 Higley and his co-authors categorized the German, Czech and Slovak mode of democratic transition as 'elite convergence'.

4 "Simulated democracy": when elite and significant groups of society "only imitate acceptance of the rules of the game" (Ilonszki-Lengyel 2009:9).

5 In my understanding, Higley and his coauthors $(2002,8)$ overemphasized the existence of elite unity among the political elite groups which took part in the negotiations, in the political as well as sociological sense. Though negotiated regime change created the rules and guaranteed the peaceful nature of the transition, no full consensus among the political elite was formed regarding either the constitutional framework to be established or public policy objectives to be followed. There was a chance for the constitution to become consolidated, and developments in the decade after the failure to craft a new constitution in 1995-97 pointed in this direction. But this trend ceased in the fall of 2006 (Körösényi 2007). 
In the following, I will focus on the problem of political polarization, while narrowing my analysis to Hungarian politics and some theoretical questions. ${ }^{6}$ First, I will ask an empirical-descriptive question: Is Hungarian politics really polarized, and if so, to what extent? We shall see that Hungarian politics has been characterized, both on the level of voters and of the elite, by significant and growing polarization (the thesis of polarization). Second, I look for an explanation for the extent of polarization. We see that polarization can be explained by the emanation or 'ripple' effect of increasing antagonism among the political elite to wider society (the thesis of endogeneity). Third, I will try to test the Schumpeterian thesis that answers the question what effect polarization has (had) on the stability of the political system and the functioning of democracy, or, to put it another way, on democratic accountability (the Schumpeterian thesis).

\section{THE POLARIZATION OF HUNGARIAN POLITICS}

So, first about the extent of the polarization of Hungarian politics, and the political elite. Has political polarization increased in the two decades since regime change? Political commentators and analysts have registered many symptoms of political polarization and have provided much anecdotal evidence to support this contention (e.g. Palonen 2009). The experience of ordinary citizens supports the researchers' observations. What deserves our attention is that the results of empirical studies correspond to the judgement of analysts. The results show, first, that the proportion of ideological self-identification has increased, and second, that the measure of political polarization was high and constantly increased in the examined period.

But before we proceed to an examination of polarization, we should ask a preliminary question. What concepts should be adopted in Hungarian politics for examining political-ideological (self-)identification? It has been the unequivocal result of two decades of research in this area that in Hungary the concepts of left and right serve as the most widely accepted political-ideological compass, coming before, for example, the labels conservative/liberal. 75-85 percent of respondents can identify their place using this left/right distinction and the proportion of those identifying themselves as being on the left or right

\footnotetext{
6 Debate and conflict are fundamental to politics; their intensity increases participation, as well as the stakes of political contestation. Covering up political conflicts has many disadvantages. In this paper I intend to highlight what the effects of "too intense" conflict and extreme polarization might be.
} 
increased in the period between 1999-2004 (Fábián 2005: 219-232). So I will consider the positions of voters, representatives, parties and elite groups on a left-right axis to be a basic measure of political-ideological polarization. An important indicator in this regard is the self-placement of voters on a left-right scale. Research done by Róbert Angelusz and Róbert Tardos in the past two decades (2000: 111; 2011: 357) shows that the distribution of voters' positions on a left-right scale (based on self-definition), having started from a normal distribution has become more polarized (see Figure 1 and Table 1). These results correspond to the results of other researchers, such as Zoltán Fábián (2005: 219), and also Zsolt Enyedi and Keneth Benoit (see Enyedi-Benoit 2011: 25). Growing polarization has occurred in parallel with an increase in partisanship as well (Tóka 2005: 27-33).

Figure 1 Distribution of voters' positions on a left-right scale based on voters'selfplacement (1994, 2003 and 2010)

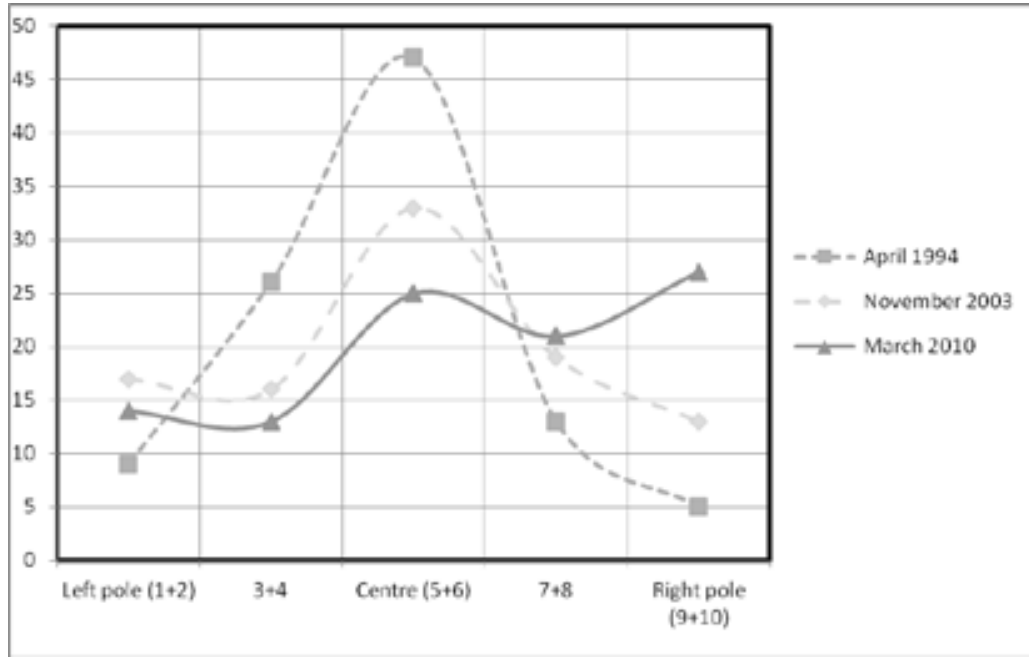

Source: After Angelusz-Tardos (2011: 357-370).

Figure 1 shows that in the middle of the 1990s the distribution of voters' self-placement on the left-right scale follows a classic bell curve, which has a sharp spike in the middle and almost completely flattens out towards the edges. In the next fifteen years (between 1994 and 2010) political realignment takes place, gradually weakening the centre and causing the bell-shape to flatten in the middle and thicken at the edges. 
The extent of polarization is measured by researchers using a polarization index (PI), which is the quotient of those at the ends of the scale and those in the middle. ${ }^{7}$ According to research by Angelusz and Tardos (2011: 357), the polarization index calculated this way based on the self-placement of citizens on a 10-degree left-right scale gradually increased from a value of 0.31 to 1.64 between 1994 and 2010 (see Table 1). ${ }^{8}$

Table 1 Polarization (poles/centre) index based on the self-placement of voters on a left-right scale (1994, 1998, 2003, 2009 and 2010)

\begin{tabular}{|c|c|c|c|c|c|}
\hline Survey year & $\begin{array}{c}1994 . \\
\text { April }\end{array}$ & $\begin{array}{c}1998 . \\
\text { February- } \\
\text { March }\end{array}$ & $\begin{array}{c}2003 . \\
\text { November }\end{array}$ & $\begin{array}{c}2009 . \\
\text { April-June }\end{array}$ & $\begin{array}{c}2010 . \\
\text { March }\end{array}$ \\
\hline PI index & 0,31 & 0,39 & 0,93 & 1,61 & 1,64 \\
\hline
\end{tabular}

Source: Angelusz-Tardos 2011: 357-370.

The international comparative studies of the European Social Survey have measured citizens' ideological self-identification on an 11-degree leftright scale every two years since 2002. Based on the data in the surveys, a polarization index can be calculated. ${ }^{9}$ The number of participating countries somewhat varies survey by survey but Hungarian politics was determined to be one of the more polarized throughout the period examined. ${ }^{10}$ Hungary was the sixth of 22 countries in 2002, the seventh of 25 in 2004, the third of 23 in 2006, the tenth of 29 in 2008, and the fourth of 19 in 2010 in terms of the highest level of polarization. If we compare results by groups of countries, Hungary's PI is around the average of the new democracies, but always significantly higher than the average of the EU-15.

7 Depending on the calibration of the scale and the method of calculation different studies use different, non-comparable indices. Resultingly, the indexes presented in this paper are not directly comparable.

8 Róbert Angelusz and Róbert Tardos (2005: 73) calculated the polarization index using a 10 -degree scale and divided the sum of the two extreme left (1-2) and the two extreme right (9-10) self-placements by the sum of the two middle (5-6) placements. Other studies indicate a similar trend. If we calculate the same index based on the research of Zoltán Fábián (2005: 231), we get a similar result, rising from a value of 0.175 in 1990 to 0.88 in 2003.

9 Calculation of the PI was done by using an 11-degree left-right scale and by dividing the sum of the $0-1$ and the 9-10 self-placements by the number of the 5 placements.

10 The Hungarian polarization index fluctuates at a relatively high level, and it always rises in election years. 
Figure 2 Polarization indexes in Hungary and different groups of EU countries (2002-2010)



Source: European Social Survey (http://www.europeansocialsurvey.org/)

The extent of political polarization in Hungary is especially high - according to research by Gábor Tóka (2006: 23-24) - considering that the number of effective parties is relatively low. There is usually positive correlation between the number of effective parties and political polarization; however, in Hungary polarization has been even higher than could be expected based on the number of parties. ${ }^{11}$

So, in Hungary between 1998 and 2010, while the number of effective parties decreased (Enyedi-Benoit 2011: 21), the political-ideological polarization as measured on a left-right scale increased, and two large opposing political blocs were formed (Soós 2012). There are three further developments that signal the appearance and growth of political polarization.

11 It can be added that other indicators also indicate constant growth in political polarization: the distance between the voters of governing and opposition parties (Angelusz and Tardos 2005: 78) and the distance between the dominant parties (Fábián 2005: 219; Bíró 2011; Enyedi and Benoit 2011: 25-26) have been constantly growing. Party identification has been gradually increasing in Hungary as well, and since the turn of the millennium the number of voters identifying with a party has been higher than the average of European countries (Tóka 2006: 25-26). 
The first one is that, beginning at the end of the 1990s, the instability of party preferences began to quickly decrease. ${ }^{12}$ By 1998 , voters" "bloc-loyalty" was established, and by 2002, their party-loyalty as well. The volatility index between parties, and between left and right, which had been extremely high in the 1990s, significantly dropped after 1998 (see Table 2). Crossing over between political camps virtually ceased by 2002 and 2006. "The election results of 2002 and 2006 (...) basically show the opposition of two large and immovable voting blocs" (Gergely Karácsony, summarizing his research on the stabilization of party preferences (2006: 64)).

The second development is that, according to research by Róbert Tardos and Zsófia Papp (2012), in the decade after the turn of the millennium the portion of strongly committed partisan voters increased among voters of MSZP and Fidesz as well, which indicates a crystallizing of voting blocs and a polarization of voter behaviour.

Table 2 Indexes of volatility (1994-2006)

\begin{tabular}{|l|c|c|c|c|c|}
\hline & 1994 & 1998 & 2002 & 2006 & 2010 \\
\hline Aggregate volatility & 25,8 & 31,7 & 18,3 & 9,0 & 35 \\
\hline Volatility between blocs & n.a. & 16,0 & 7,2 & 2,1 & n.a. \\
\hline Volatility of votes for the governing parties & $-25,8$ & $-12,2$ & $-3,6$ & 2,1 & n.a. \\
\hline
\end{tabular}

Source: for the 1994-2006 period, Karácsony 2006, 66; for 2010, Enyedi-Benoit 2011, 20.

The third development is that the decrease in crossing over between political camps shows up not only in voting behaviour but in everyday relationships as well. As we know from research by Róbert Angelusz and Róbert Tardos (2011: 358-365), since the turn of the millennium membership of a political camp has affected citizens' networks of personal relationships. In strongly attached, close relationships of individuals a tendency to political homophily has prevailed and has gradually strengthened, according to research results from 2003 and 2009. Personal circles of acquaintances and networks of relationships have become politically more homogenous. The same research also shows that this relationship homophilia is more pronounced at the ideological poles than it is in the middle, and that it increases with intensity of political interest (Angelusz-Tardos 2011: 362-365).

It has to be noted, however, that the 2010 elections were a turning point in many respects. The elections produced a dramatic increase in volatility,

12 In Western Europe for the same period average volatility slightly dropped, while in Eastern Europe it slightly rose (Schmitt-Scheurer 2011: 318). 
disintegrated the two-block system (Soós 2012), and produced a new partysystem. ${ }^{13}$ After 2010 the opposition of the incumbent centre-right coalition divided into a few splinter groups and parties on the left and a radical opposition on the right (Jobbik). This development might have an impact on patterns of ideological polarization in the future. However, to analye the post2010 period is not the goal of this article.

\section{THE ELITE}

It is not only voter behaviour and perception that have become so ideologically polarized. In the past two decades several studies have focused on the political and ideological belief systems of various segments of the elite, including their placement on the left-right scale.

We know the self-placement of the elites of each party on an 11-degree scale from the findings of the elite survey conducted by the Election Research Program at the time of the 2010 elections among candidates for Parliament. ${ }^{14}$ According to these results, candidates' self-definitions do not differ significantly from the self-definitions given by voters from the same party, measured in the same survey. Both show strong polarization. MSZP has a position of 1.6 on the scale both among its voters and the elite, while Fidesz occupies a position of 7.4 among the elite, and 7.8 among its voters - the distance between the voters is slightly more than the distance between the candidates (Enyedi-Benoit 2011: 37).

According to Hungarian data from the INTUNE international elite survey of representatives, the polarization index calculated on the basis of selfplacement on an 11-degree left-right scale was 1.38 in 2008, and 1.86 in $2009 .{ }^{15}$ The PI value calculated from the results of the 2010 elite survey conducted by the Election Research Program among members of Parliament was 2.86 , which shows more extreme polarization among representatives.

An elite survey conducted in the Institute of Political Science of the Hungarian Academy of Sciences (Csurgó-Megyesi 2011: 152) which included a much wider circle of the political elite than just candidates and

13 The 2009 elections for the European Parliament already signalled this change in voter behaviour. As a consequence of this change the support for the left-liberal block collapsed in the 2010 landslide parliamentary elections.

14 http://www.valasztaskutatas.hu/eredmenyek-en/adatbazisok

15 http://www.intune.it/ The calculation method for the PI: the sum of the 0-1 and 9-10 selfplacements divided by the 5 placements. 
representatives also examined the ideological polarization of the elite (on a 9-degree scale). As can be seen in Figure 3, even in this very wide sample, which included public servants, local government officials, church and union leaders, as well as leaders of sports and other social organizations, significant polarization has occured. The inclusiveness of this 401 person sample is indicated by the fact that in 2009 members of the Parliament accounted only for 6.7 percent of the sample and leading party officials for 1.7 percent (Csurgó-Megyesi 2011: 152).

These results confirm the findings of the previous studies that the ideological polarization of the Hungarian political-public elite significantly increased in the decade after the turn of the millennium (Girst-Keil 2011: 317), a fact which is illustrated in Figure 3. The polarization index measured here also increased significantly, from a value of 0.62 in 2001 to 1.25 in $2009 .{ }^{16}$ But this does not simply reflect a case of the extremes becoming stronger and the centre becoming weaker. Self-placement decreased in all three positions in or near the centre and increased in all three positions on the left and right. This means that the centrifugal tendency affected the whole left-right scale; the whole of the bell-curve became flatter.

Growing elite disunity, according to the new elite paradigm, may destabilize liberal democratic regimes. But in Hungary, no clear evidence supports this thesis. Either disunity is not so sharp (as unity is required by the new elite paradigm) or it does not produce the assumed consequence of instability. Having seen the figures about polarization, let us now turn to the problem of regime instability. Although political protest and direct participation in demonstrations have increased since the autumn of 2006, these endeavours were channelled and institutionalized by constitutionally-defined procedures like public initiatives and referendums (2008), the foundation of new political parties (Jobbik) and were expressed through changing voting behaviour at the 2010 general elections. The latter brought a landslide victory for the moderate Right Fidesz-MPP. The two-thirds parliamentary majority made it possible for Fidesz-MPP and its parliamentary ally to introduce a new constitution on $1^{\text {st }}$ January, 2012, but one which fits with constitutional procedures and has not brought a radical change in the nature of the system of government. To sum up, a peaceful seizure of power has not been challenged by any means in Hungary. Growing political polarization has instead caused a realignment of electoral behaviour, a radical change in the party system and produced a landslide victory for one of the competing political blocks.

16 The PI was calculated by dividing the sum of the $1-2$ positions and the $8-9$ positions by the 5 positions. 
Figure 3 Self-placement of the political elite on a 9-degree scale, as a percentage of all surveyed, and the polarization index (PI) (2001 and 2009) $(1=l e f t ; 9=$ right)

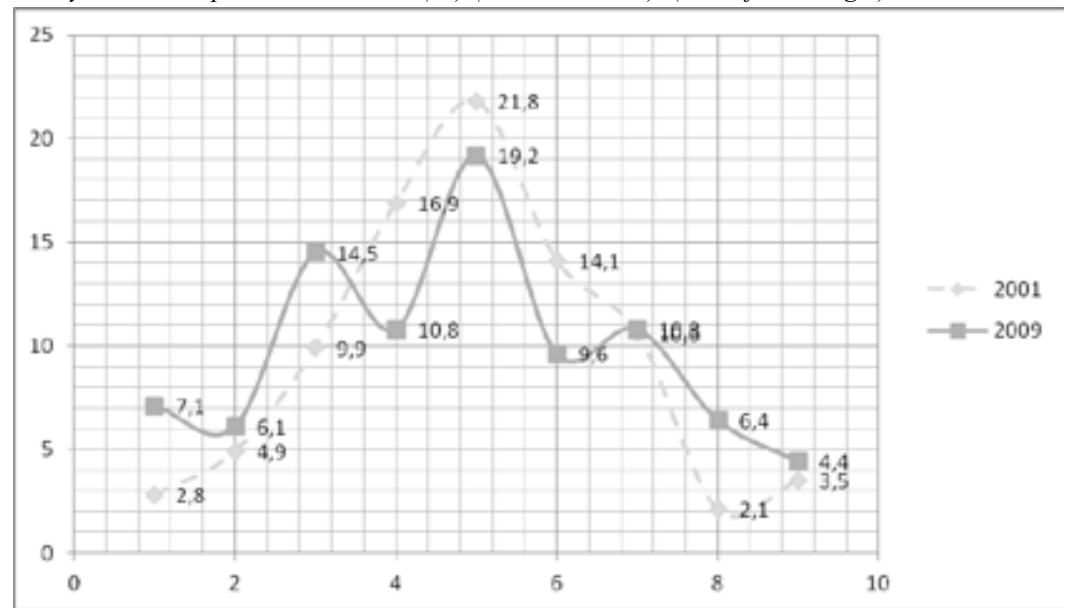

Source: Elite survey by the Institute of Political Science of the Hungarian Academy of Sciences. The PI values are based on the author's own calculations.

To summarize the first part of this article we can conclude that in Hungarian politics between 1990 and 2010 growing political polarization took place in the left-right dimension, and in the five years before the 2010 elections it became extreme. This polarization occured with voters as well as the political elite.

\section{EXPLANATIONS FOR POLARIZATION}

Political scientists and analysts considered the ideologization and polarization of Hungarian politics to be extensive, or even excessive, even in the 1990s. How can we explain the strong polarization of Hungarian politics that can be observed subsequent to the democratic transition? In my opinion the following factors have undoubtedly contributed to the process of polarization.

The first explanatory factor is the heavy role of ideology, which has affected Hungarian politics in several ways. First, the fast pluralization of the political spectrum in 1989-90 and the accompanying task of political mobilization created a structural necessity. For the newly-established political parties (lacking predecessors and traditions), in order to succeed in 
terms of political mobilization, it was imperative to differentiate themselves as clearly as possible from their rivals, which led them to emphasize ideological differences. Second, ideology-producing intellectuals, especially by international comparison, played an unusually prominent role, which, though varying in intensity, remained constant throughout the period. ${ }^{17}$ Third, the prominent presence of ideology-oriented politicians, who, in contrast to their office-oriented, pragmatic peers - who take the political preferences of voters as a given - wish not only to follow, but to shape citizens' preferences. The mobilization function of political parties, the ideology-producing role of intellectuals and the presence of ideology-oriented politicians reinforced competitive elite-strategies in the 1990s, which later became a permanent feature of Hungarian politics.

The second explanatory factor can be found in the subcultural elements which acted to strengthen the internal cohesion of rival elite groups and the backgrounds of parties. These subcultural groups are bound together by (besides common socio-cultural factors and clientele-interests) looser or stricter ideological components as well. Political subcultures had already played a role in politics and party formation of the end of the 1980s. But now I would like to focus on the party strategies that could be observed from the middle of the 1990s and which continued after the turn of the millennium. Through these strategies the parties consciously tried to bind pre-existing civil groups and organizations (e.g. ethnic, veteran, legacy organizations, associations, churches, foundations and think tanks) to themselves, or to create organizations or movements often labeled "independent" or "nonpartisan", and thus strengthen their social, cultural, intellectual and economic background (Csizmadia 2003; Enyedi 1996). The parties and the leaders of the political camps offered symbolic and ideological signs and political narratives to the members and sympathizers of these organizations, civil groups and movements and by this created/maintained the political camps and subculture.

Third, I consider the appearance of political populism in national politics and among big parties to be an independent factor in the growth of polarization. Economic populism in a wider sense has been present and used since the 1990s until today by parliamentary parties - both on the left and the right, in government and opposition - to win over Hungarian voters who exhibit predominantly leftist attitudes in economic and social policy (e.g. the program of "welfare regime change", the promise of 13th and 14th

17 Beside a broad body of literature on the topic there alsois exists empirical research on the political character of public intellectuals (Kristóf 2005; 2011). 
month pensions, etc.). Political populism and anti-elite sentiment was also present in Hungarian politics in the 1990s, but it was limited to marginal groups, or parties that were small or played only a temporary role in national politics (e.g. the Smallholders' Party, or MIÉP). This situation changed after the turn of the millennium with anti-establisment political populism making an appearance in mainstream parties and the political elite. After losing the 2002 elections the leader of the political right, Viktor Orbán, performed an explicit - in the narrower, political sense - populist turn. He organized an extra-parliamentary, "above parties" movement by founding so-called "Civil Circles" and began to use anti-establishment rhetoric targeted at former Communist functionaries who had become wealthy entrepreneurs during the process of privatization, international financial institutions and multinational corporations. This populism was not limited to political rhetoric but appeared in the party's opposition strategy (e.g. the forcing through of the 2008 "social referendum"), and after the election victory of 2010 in government policy as well. According to Higley's paradigm, this division of the elite and the emergence of strategies aimed at division means, by definition, the opposite of elite-consensus, or its weakness.

The fourth - and, in my opinion, decisive - factor in the development of the polarization spiral is the contribution of political leaders. The important role that political leaders have played in the formation of political preferences in Hungary is supported not just by the work of political analysts and political theorists but by empirical studies as well. Several authors have emphasized the outstanding role and effect of political leaders in Hungarian politics. Körösényi (2001) analyzed the strengthening of the role of the prime minister, using Thomas Poguntke and Paul Webb's concept of presidentialization. Enyedi (2005) explained the reformation of the party system through the strategic decisions made by the leader(s) of Fidesz. Tóka (2006) pointed to the personalization of electoral competition and the unusual extent of voter leadercentric attitudes, while Ilonszki and Lengyel (2010), using James MacGregor Burns' typology, wrote about the preponderance of the transformative style of leadership. These results also mean that the polarization of citizens' preferences on a left-right scale is not simply something given (exogenously) to parties, but is the result of the strategies of the parties and their leaders; that is, it is an endogenous factor. ${ }^{18}$ Personal elements and the dominant style and

18 The role of exogenous factors cannot be denied, however. Parties at least in part build on exisiting attitudes and socio-psychological characteristics. One such factor is the growing dissatisfaction with the new system - democracy and the capitalist market economy which arose after the regime change and was caused by economic contraction, growing 
character of political leadership over the past decade have also significantly contributed to polarization. The rivalry of the two opposing political leaders (Viktor Orbán and Ferenc Gyurcsány) with their confrontative styles, constant raising of the stakes and readiness to take risks resulted in the strengthening of political polarization. ${ }^{19}$

Fifth, and last, I would like to mention a factor which questions the applicability of Higley's elite-consensus paradigm to the Hungarian transition at its starting point. This is the lack or weakness of an underlying consensus. According to this explanation, Hungarian politics is characterized not simply by strong political-ideological polarization but from the very beginning has lacked the underlying consensus necessary for the efficient functioning of democracy, which, in Higley's approach, is the basis of elite-consensus. According to this view it is a mistake to regard the agreement of the Hungarian transition as consensual: in 1989-1990 only a temporary compromise was struck..$^{20}$ The notion of a lack of an underlying consensus is supported by the delegitimizing strategy of the parties. As part of an underlying consensus, the competing parties should recognize the legitimacy of one another. Contrary to this, the Hungarian right has called into question the national commitment of the left and the left the democratic commitment of the right, from the beginning of the 1990s until current times. The lack of an underlying consensus also explains why, instead of debates about public policy, the focus of Hungarian politics has consisted of symbolic (legitimizing and exclusionary) discourses. The delegitimizing strategies of the parties strengthen the intensity of the left-

unemployment and other economic difficulties which had been on the rise since the beginning-middle of the 1990s, and the alarming loss of trust in political institutions (parties, Parliament, the government) (Boda-Medve-Bálint 2010). All this does not lead to politicalideological polarization by itself though. Nor do institutional factors (first and foremost the electoral system), which are often cited as an explanation for the drop in the effective number of parties. The decrease in party numbers and the bipolarity of the party system, however, do not explain polarization, a fact which Sartori (1976) reached (arriving at precisely the opposite conclusion) in his theory of party systems. The main thesis of my paper is that the cause of the ideological polarization of Hungarian politics is endogenous, meaning it relates to the strategies and actions of political actors.

19 According to some analysts the rivalry between the two political leaders can be described as a game of chicken, as known from game theory (Gergely 2006). I think a similarly enlightening model is the dollar-auction game where the rivals' commitment to an earlier chosen strategy which threatens to end in failure escalates because of the need to justify their earlier investment. What adds interest to this problem of "entrapment" from the viewpoint of this paper is that, according to psychological experiments, a bigger stake and more responsibility increases the measure of entrapment, in contrast to what intuition would say (Plous 1993: 248-251).

20 This compromise only worked for a while: the political unity of the opposition and negotiations with the Communists unraveled by the fall of 1989 . 
right opposition and ideological-political polarization. ${ }^{21}$ Polarization, from the middle of the decade until after the turn of the millennium, has weakened the basic values and institutions of the political system.

\section{THE CHICKEN-EGG PROBLEM}

In my view, the above factors have all contributed to the strong polarization of Hungarian politics. However, I haven't explicitly addressed the question yet of which came first - polarization of voters' preferences, or the political leaders' strategy of polarizing the voters? Is there a causal relationship between voter polarization and elite polarization? If there is, what is it? Or are both explained by other factors? Do vote-maximizing parties follow the 'flattening out' process indicated by the preference-distribution of voters, or, quite the reverse: does a centrifugal trend cause polarization as a result of the parties' strategies?

In political theory the tradition associated with the names of Weber, Schumpeter, Sartori and Riker, highlights the active role of political parties, leaders and the elite in forming the political preferences of voters (Körösényi 2010; Pakulski-Körösényi 2012). In the paradigm of heresthetics the nature and intensity of political-ideological conflicts is the consequence, first and foremost, of party/elite strategies. One (smaller) branch of political sociology and the literature of cleavages, following Rokkan, emphasizes that the sociological division of society is not necessarily a politically relevant division, the latter being constituted by the actions of political actors (Sartori 1969; Enyedi 2005). This is confirmed by a part of the literature on the relationship between voters and parties. According to empirical research conducted in the United States which examined political communication, parties and public opinion, political polarization is a top-down phenomenon and the elite orientate the voters (Fiorina et al 2008; Levendusky 2010; Zaller 1992). ${ }^{22}$ The once-again increasing role of parties since the $1980 \mathrm{~s}$, as well as

21 The underlying consensus was quite weak even from 1990 onwards (Körösényi 2007), but it was openly questioned after the fall of 2006. There were many signs of this: the protest movement of the fall of 2006, police violence, the opposition's boycotting of the prime minister's speeches in Parliament, the questioning of the legitimacy of the government and even of the Constitution, by the opposition and extra-parliamentary groups, the opposing views of the constitutionality of the 2008 referendum and the conflict over the passing of the new Constitution in 2010-11.

22 However, others write about the parallel spread of ideological polarization among voters and the elite at the same time (e.g. Abramowitz and Saunders 2008). 
the increasing partisanship of voters, are both consequences of ideological polarization among the parties and the political elite (King 1997; Layman és Carsey 2002; Hetherington 2011).

The role of the elites is even more pronounced in post-communist countries than in countries where there was a continuity of democracy. With the pluralization of politics, the political division and ideological identification of the elite occured much more quickly than that of wider society. The new parties which determined the development of politics in Hungary were based on narrow groups of the intellectual elite. They had a definite ideological character from the beginning. According to the assessments of analysts and political scientists, political conflicts - when compared to contemporary Western European politics - focused on ideological questions to an unusually high degree (Ágh 1993); that is, ideology played a significant role in the creation of political camps.

From Hungarian studies of the elite(s) and citizens over the past two decades, two general tendencies can be observed. One is that the ideological character of the political elite is more pronounced and its self-definition on the ideological scale is more polarized ${ }^{23}$ than that of citizens (Körösényi 1999: 58-70; Enyedi 2005: 12). Members of the political elite (especially representatives) move further from the political centre. The other tendency is that the ideological self-definition of the voting blocs of parties follows the changes in the dynamics of politics and the party system and the relationships between the parties, so the self-placement of citizens on a left-right scale also shows a polarizing trend. This is better illustrated by the index of sympathyantipathy among the potent voting blocs of parties. Research by Angelusz and Tardos (2000: 105-113) which covers the period between 1991 and 1998 showed that changes in the sympathy-antipathy index can be well explained by changes in politics and party relations. To put it another way, the changes in political dynamics resulted in changes in citizens' preferences. The active role of parties and the political elite in shaping citizens' preferences was revealed in Hungarian empirical literature by way of Zsolt Enyedi's (2005) case study of Fidesz, which focused precisely on this question.

To summarize, I think, based on the above, that it may be justified to regard parties and the political elite as the principal actors of polarization. We would also be justified in drawing the conclusion that voters follow the polarization which occurs among parties and the elite after a certain lag. This provides an answer to the chicken-egg question. Parties and political elites generate political division and the political polarization of voters. Polarization which

23 A similar tendency can be observed on the liberal-conservative scale. 
takes place among elites makes the political-ideological profile of voting blocs more pronounced, and this results in increased polarization among voting blocs.

\section{THE EFFECTS OF POLARIZATION ON THE FUNCTIONING OF DEMOCRACY}

From Schumpeter's thesis it follows that polarization into two hostile camps weakens the advantages of democracy. In the third and last part of my article I explore this contention through addressing the following question: what effect does the depth of the division of citizens and the political elite and the intensity of political polarization have on democratic accountability and the effectiveness of democracy?

The promise of democratic elitism has been the reconciliation of elite rule and democracy: this refers to a state wherein the elite does rule, but it becomes accountable and replaceable. According to the new elite paradigm in the thesis of John Higley and his co-authors, the overly deep division of the elite weakens the stability of democracy. We saw above that growing polarization itself has not undermined political stability, in contrast to Higley and his co-authors' contention that it does. Instead, and this is my hypothesis, it weakens the accountability of incumbents.

In the following, I will try to explore the mechanisms through which this weakening effect prevails. ${ }^{24}$ I distinguish five effects that work in this direction: psychological and information, moral, public policy, patronage and the delegitimizing effect.

\section{The Psychological and Information Effect}

Ideological-political polarization, depicted by Anthony Downs (1957) as a U-shaped distribution of citizens' preferences on a left-right scale, produces a "camp-mentality" on the opposing sides of the political-ideological spectrum. This situation, often characterized in Hungarian political literature and journalism as a "cold civil war", results in the rise of an "Us vs. Them" awareness. Tribal politics and the "camp-mentality" breaches and

24 Polarization, besides its negative consequences, may have some benefits as well. One such effect is that elite polarization leads to increased political participation (Crepaz 1990). Another is that the consistency of the average voter's attitude-ensemble increases (Levendusky 2010). 
weakens independent (of party-political interest) public opinion ${ }^{25}$, and has a disinformational effect. What explains this?

It is an old observation that people talk more willingly - about politics as well as other subjects - with others who have the same views, than with those who have different ones (Berelson 1952: 323). The segmentation of political communication leads to a splintering of public opinion. Political homophilia and the formation of a camp-mentality has a negative effect on citizens' information levels and also on the likelihood that the information they receive is "balanced". Growth in political polarization thus increases the chasm between the "political reality-perceptions" of groups with different political outloooks. The stronger the camp-mentality, the more biased citizens' information and the less objective their picture of "political reality" becomes. ${ }^{26}$ One of the reasons for this is confirmation bias; a preference for information that corresponds to our pre-existing hypotheses and beliefs rather than for information which contradicts it (Plous 1993: 233). Those with strong political views are more willing to listen to news that confirms their political beliefs and the analyses of their own party leaders, while - through selective perception - suppressing and filtering out uncomfortable information (Plous 1993: 15-21). This is reflected in media consumption habits. Most people read, listen to, or watch media products that conform to their political beliefs. ${ }^{27}$ The selection and framing of issues is performed by a partisan media, which, in turn, affects consumers'/citizens' political opinions, reinforcing the filtering effect. According to some studies the need for profitability of the commercial media also plays into this effect (Bernhardt et al. 2008). So, the growing polarization of society increases the partiality of the media, which - as an independent factor - has a negative effect on the information level of media consumers and citizens, making them even less objective.

25 "If ... attitudinal positions expressed on a scale shift extremely from a normal distribution, this signals that the chances of convergent communication, attuned to one another ... severely decrease, and, in fact, the somewhat unified semantic universe, which is a precondition of democratic communication, evaporates" (Angelusz-Tardos 2011: 357).

26 This can be observed with so-called adverse media bias. According to social-psychology experiments, selective perception often leads to media consumers from the other end of the political spectrum with strong party loyalty regarding the same media products as being biased against their own party (Plous 1993: 20).

27 One reason for this is that, although having better-informed citizens would benefit every voter, individual citizens, because of their negligible influence on the outcome of the elections, are not interested in gaining a higher level of information (the thesis of rational disinformation). Individual citizens thus appreciate the entertainment value of media more than its news or information value (Bernhardt et al. 2008). 
Media consumption habits shaped by political polarization and campmentality and media bias decrease the efficiency of voters' decisions; that is, through the "disinformation" mechanism, they distort election results. By "distortion" I mean that, given a specific (polarized) preference-distribution or camp-mentality, the selective perception of political reality and media bias lead to different types of voter behaviour than would be the case if both camps got their information from the same "neutral", objective media. With are ent from how they would be if The growth in polarization means not only that the distance between the political values and goals of the political camps increase, but also that there will be a chasm between their information about a given situation and their picture of political reality (such as the processes leading up to it and the underlying causal connections). In Hungary several studies have shown that there is a correlation between media consumption habits and political preferences (see e.g. Gazsó 2005).

\section{The Moral Effect}

Due to ideological-political polarization and the camp-mentality, the role of camp membership and (party)political loyalty - in place of professional competence and aptitude, as well as moral integrity - increase to an extent that might be considered pathological. A double standard becomes operative, where violating basic norms is acceptable on 'Our' side, while being unforgivable on the 'Other'. The disappearance of a common standard leads to moral relativism and gives rise to political irresponsibility and corruption. All this reduces the efficiency of democratic control and accountability as the incentivising effect of democratic elections on incumbents, as depicted in Friedrich's rule, weakens. ${ }^{28}$ With a more polarized political spectrum the role of partisan voters increases, while the proportion of swing voters is reduced. When a government can count on the votes of its own camp in all circumstances, the number of swing voters is down to a minimum and the fight for the voters of the other camp is hopeless, what incentive does the governing party have to keep its election promises? What would motivate it to govern efficiently and responsibly, in tune with the public interest? Democratic control and the accountability of politicians is only effective if

28 A further psychological effect of political polarization is that in place of rational/deliberating voters, expressive voters with strong political loyalties are created. Thus voting for the candidate on the other side becomes meaningless or "irrational", even if the incumbent on the favoured side performs abysmally (is corrupt, etc.). 
a significant portion of voters do not belong to either political camp. But for the undecideds, as their votes depend on situative factors, evaluation of government performance means a lot.

In a polarized situation a significant number of undecided/median voters motivates parties to manipulate the beliefs of swing voters about possible policy choices and their consequences. Using policy-distortion or heresthetics they try to paint reality and the causal relations of the world of public policy (that is, the actual situation and the connections between specific policy inputs and outputs) in a way that the presumed implications of intended or pursued government policies correspond to the outcomes preferred by undecided/ median voters (Hindmoor 2004; Schultz 2008: 1079). The stronger the polarization and the further the parties are from the median position, the more dependent swing voters' actual party choices are on the success of the given party's efforts at policy-distortion and heresthetics.

I believe these developments occured to a great extent in Hungary after the turn of the millennium. Even if a U-shaped distribution of preferences did not materialize, the curve depicting the distribution flattened. The extremes grew and camp mentality took hold. Political parties entered territories - the middle and lower levels of public administration, universities, health-care institutions - they had not been present in during the 1990s. They spread their influence - by leadership appointments and other means - into areas such as theatres and cultural institutions. Signs appeared of the operation of a double standard and the spread of moral relativism as a consequence of tribal politics (such as the appearance of groups of intellectuals who influenced public opinion; who were organized on the basis of political sympathy; that stood by and demanded freedom from punishment for politicians and public personalities who were charged with common criminal offenses).

\section{The Public Policy Effect}

If the incumbent party makes good that its policies are always in accord with its election promises, public policy - in the case of a state of growing polarization - starts "zig-zagging" over successive government cycles . This, according to my hypothesis, reduces the efficiency of public policy in several ways. First, due to the effect of polarization, public policy diverges from the median position that represents the social optimum (Schultz 1996; 2008). This is because the incumbent party will not pursue a centrist public policy - will not adjust to the median position - as its own voters would not identify with it, and the number of centrist voters has decreased. Second, the 
frequent change of direction reduces the efficiency of public policy, also in the sense that frequent changes of direction or regime in public policy create great social costs. The costs of the introduction of a new direction of public policy have to be paid for, while, because of the short life-span of the public policy regime - changing with each goverment cycle - its benefits often fail to materialize. Affected areas of public policy in Hungary in the previous two decades include, for example, public and higher education, health-care, social and income policy, drug and criminal policy.

In systems of government based on a division of power, a further public policy effect of polarization might be that deadlocks leading to indecision become more common, while public policy renewals (reforms) get sidetracked (McCarty n.d.). As, in a system based on the division of power, successful public policy decisions require wide consensus - or at least the neutralization of veto points -, polarization increases the motivation of the opposing side to block government policy in every possible way. In the Hungarian governmental system one effective instrument of public policy veto was the activation of the mechanism of judicial review. In the 1990s, as a consequence of laws requiring a two-thirds majority and the lack of consensus due to political polarization, the role of the Constitutional Court (rather than Parliament) increased in interpreting the Constitution, and through that, in constitution- and lawmaking. Another possible veto-instrument was referendum by popular initiative (one spectacular example of its successful use occurred in 2008).

Finally, stronger polarization offers more incentive to create strategic disagreement and practice shifting responsibility (the blame game), which in turn has a negative effect on the political bargaining process (McCarty n.d., 6). From the recent record of Hungarian politics a good example is the formation of the new Constitution in 2010-11. As the opposition couldn't block Fidesz's two-thirds majority from creating a new Constitution it decided to withdraw from the constitution-making process. This boycott-strategy questioned the legitimacy of the whole process, as the charge of "one-sided" constitutionmaking seemed more effective at discrediting the new Constitution. The withdrawal of the opposition - at least in the short run - caused only minor trouble for Fidesz as it justified the creation of the new Constitution in the first place by the need to break with the previous two decades, which was reconfirmed by the withdrawal of the opposition. However, in the mid and the long term this might weaken, or even completely undermine the legitimacy of the new Constitution (Jakab 2010).

To summarize, political polarization in Hungary (A) in the area of traditional goverment policies - where the classic majority rule of decision- 
making applies - reduces the efficiency of public policy by making it "zigzag", while (B) in areas of public policy covered by the division of powers it has a "conservative", status quo-maintaining effect, and (C) in several other areas it leads to strategic disagreement. As a consequence of these effects, the efficiency and ability to renew of the affected public policies might weaken.

\section{The Patronage Effect}

The growth in polarization has affected appointment policy in filling positions in public administration, government, state and public institutions. Because of the growing inability to reach a consensus, filling positions that require parliamentary nomination and/or approval has become more and more problematic. The time needed to fill these positions, as well as the number of positions left unfilled has increased. In the United States, for example, this has been true in the case of federal judges. In Hungary these positions included Constitutional Court justices, parliamentary comissioners, the president and vice-president of the National Audit Bureau and the chief justice of the Supreme Court. Polarization has also affected the quality of the personnel who have filled these positions. Rather than persons who are outstanding in their field but have stronger characters - and who are sure to be vetoed by one of the parties - the proportion of mediocre candidates has grown in the affected bodies.

\section{The Delegitimizing Effect}

In the model of the median voter, as the outcome of the elections does not cause dramatic changes in government policy and the side that has lost the election can reasonably expect to have a good chance of winning the next time, the stakes of the political competition, or game are relatively low. The winner does not seek to eliminate or criminalize its opponents. Because of the low stakes, the chance of winning and the force of the underlying consensus both political camps expect the rules of the game to remain unchanged and expect the other side to keep to them.

In the case of elite division and political polarization, the situation changes. The stakes of politics rise. First, the stake represented by the elections rises in the area of public policy, because - as we could see in the Hungarian examples above - a change of government may result in radically different, even completely opposing public policy. 
Second, besides public policy, politics is going to have a constitutional stake as well. The reason for this is that the lack of an underlying consensus might mean differing constitutional aspirations; that is, an intention to change the rules of the game (more precisely, this shows that the game metaphor is inadequate for depicting politics, since in a game rules are exogenous to the players, while in politics the rules are made by the political actors who are the players themselves). An opportunity to change the rules in Hungary requires a two-thirds majority in Parliament. In the past two decades two governments (the Horn government in the 1990s, and the second Orbán government after 2010) have had this opportunity. The Horn government in 1994 modified the Constitution, while the second Orbán government adopted a new Constitution.

Third, the weakening of the boundary between political and legal responsibility might reduce politicians' immunity from legal accountability. Western democracies give legal immunity to representatives and other leading public officials for the time of their mandate ensuring that their political activity is protected from criminal or other official sanctions or other arbitrary procedures. The possibility or practice of the suspension of immunity, or the criminal accountability of politicians who have left their office raises the stakes of politics. Stigmatization of political opponents and the criminalization of politics are possible effects of political polarization. In Hungary, criminal procedures against politicians have been part of party political struggles since the 1990s. With members of the elite who had been charged or been under investigation, pro and contra arguments often followed political camp divisions. Investigations and criminal procedures against members and officials of the previous government (after it lost the elections and left office) and the leaders of state companies were initiated by the new, opposing government and appeared at a massive scale after the turn of the millennium. Since in the Hungarian justice system the prosecutor's office did not belong to the minister of justice but was independent, incoming governments set up special "supervisory offices" - which carried out examinations and conducted investigations - for the purpose of starting procedures against officials of the previous government.

Polarization increases the stakes of getting into government. In the median voter model the stakes are low, as - since the rules do not change - there is always a chance of winning and getting into government. If not now, then at the next election. With a polarized political spectrum the stakes of losing the governing position increase, which motivates the incumbent party to stabilize its position by institutional means, changing the rules to its advantage. The textbook example of this is changing electoral laws, or the practice of "gerrymandering" as it is known in American politics. In Hungarian politics 
good examples of this are the modification of the local election law in 1994 and 2010 by the governing majority, or the modification of the parliamentary election system before 1994, and its comprehensive reform, begun in 2011, and, in many respects, the new Constitution in 2012.

In the third part of my article I described how political polarization weakens the responsivity and accountability of governments through psychological and information, moral, public policy, patronage and delegitimizing effects. As a consequence of this, political leaders can pursue more independent - or, if you like, arbitrary - policies.

\section{SUMMARY}

Finally, I will summarize the three theses of my essay. First, I think I have succeeded in proving the polarization thesis, according to which between 1990-2010 political polarization increased to a large extent in the Hungarian political elite and among citizens, although it has not undermined the stability of the political system. Second, I gave an endogenous explanation for the phenomenon of polarization. The political-ideological profiles of the voting blocs and the strengthening of polarization between them have been consequences of polarization in the party strategies and among the elite, and they have become more pronounced because of them. Third, by theoretical discussion and empirical examples taken from Hungarian politics, I demonstrated that although growing polarization has not generated regime instability, it reduces, or might reduce - according to the Schumpeterian thesis - the efficiency of the operation of democracy. I presented five mechanisms of the effects of ideological polarization which weaken democratic accountability.

\section{REFERENCES}

Abramowitz, Alan I. and Kyle L. Saunders (2008), "Is Polarization a Myth?" The Journal of Politics Vol. 70, No. 2, April, pp. 542-555.

Angelusz, Róbert - Róbert Tardos (1999), “A választási erőtér blokkosodása 19941998", in Kurtán, Sándor, Péter Sándor and László Vass eds., Magyarország politikai évkönyve, 1999. Budapest, Demokrácia Kutatások Magyar Központja Közalapítvány, pp. 619-636.

Angelusz, Róbert - Róbert Tardos (2000), Pártok között szabadon, Budapest, Osiris Angelusz, Róbert - Róbert Tardos (2005), “A választói tömbök rejtett hálózata”, in: Angelusz, Róbert - Róbert Tardos eds.,Törések, hálók, hidak: Választói magatartás 
és politikai tagolódás Magyarországon, Budapest, DKMKA, pp. 65-160.

Angelusz, Róbert - Róbert Tardos (2011), "Régi és új törésvonalak, polarizáció, divergenciaspirál", in: Tardos, Róbert - Zsolt Enyedi - Andrea Szabó eds., Részvétel, képviselet, politikai változás, Budapest, Demokrácia Kutatások Magyar Központja Alapítvány, pp. 347-382.

Ágh, Attila (1993), “The 'Comparative Revolution' and the Transition in Central and Eastern Europe", Journal of Theoretical Politics Vol. 5, No. 2, pp. 231-252.

Bartolini, Stefano (2000), The political mobilization of the European left: 1860-1980; The class cleavage, Cambridge, Cambridge University Press

Baylis, Thomas A. (2012), "Elite Consensus and Political Polarization: Cases from Central Europe" Historische Sozialforschung Vol. 37, No. 1, 90-106.

Berelson, Bernard (1952), "Democratic Theory and Public Opinion". The Public Opinion Quarterly Vol. 16, No.3 (Autumn 1952), 313-330.

Bernhardt, Dan - Stefan Krasa - Mattias Polborn (2008), "Political Polarization and the electoral effects of media bias", Journal of Public Economics 92, pp. 10921104.

Best, Heinrich - John Higley, eds. (2010), Democratic Elitism: New Theoretical and Comparative Perspectives, Leiden and Boston, Brill

Bíró Nagy, Andás (2011), “Az új pártrendszer térképe - Programok, pártelitek és szavazótáborok a 2010-es választások után”, in: Sándor, Péter - László Vass eds., Magyarország politikai évkönyve 2010-ről, Budapest, DKMKA

Boda Zsolt - Medve-Bálint Gergő (2010), Institutional trust in Hungary in a comparative perspective: an empirical analysis, in: Füstös, László - Ivett Szalma eds., European Social Register 2010: Values, Norms and Attitudes in Europe, Budapest, MTA PTI and MTA SZKI, pp. 184-202.

Crepaz, Markus. M. L. (1990), "The impact of party polarization and postmaterialism on voter turnout. A comparative study of 16 industrial democracies". European Journal of Political Research Vol. 18, No. 2., pp. 183-205.

Csizmadia Ervin (2003), Politika és értelmiség. Pártok, agytrösztök, hálózatok, Budapest, Századvég Kiadó

Csurgó, Bernadett and Boldizsár Megyesi (2011), Elit meghatározások és elitcsoportok, in: Kovách, Imre ed., Elitek a válság korában, Budapest, Argumentum, pp. 143176.

Downs, Anthony (1957), An Economic Theory of Democracy, Harper and Row, New York

Duverger, Maurice (1959), Political Parties, London, Meuthen

Enyedi Zsolt (1996), "Organizing a subcultural party in Eastern Europe: the case of the Hungarian Christian Democrats", Party Politic Vol. 2, No.3, pp. 377-396.

Enyedi, Zsolt (2005), The of agency in cleavages formation, European Journal of Political Research Vol. 44, No. 5, pp. 697-720.

Enyedi, Zsolt - Ken Benoit (2011), "Kritikus választás 2010. A magyar pártrendszer átrendeződése a bal-jobb dimenzióban”, in Enyedi, Zsolt - Andrea Szabó - Róbert Tardos, eds., Új képlet: a 2010-as választások Magyarországon, Budapest, DKMKA, pp. 17-42. 
Fábián Zoltán (2005): “Törésvonalak és a politikai-ideológiai azonosulás szerepe a pártszimpátiák magyarázatában”, in: Angelusz, Róbert - Róbert Tardos eds.,Törések, hálók, hidak: Választói magatartás és politikai tagolódás Magyarországon, Budapest, DKMKA, pp. 207-242.

Fiorina, Morris P. - Samual A. Abrams - Jeremy C. Pope (2008), "Polarization in the American Public: Misconceptions and Misreadings", The Journal of Politics Vol. 70, No. 2, April, pp. 556-560.

Gazsó Tibor 2005. Támasz vagy akadály? A média szerepe a magyar választók politikai tájékozódásában. in: Törések, hálók, hidak: Választói magatartás és politikai tagolódás Magyarországon. Szerkesztette Angelusz Róbert és Tardos Róbert. Budapest, DKMKA, 385-406.

Gergely, Zsófia (2006), “Gyáva nyulas játékot űz Gyurcsány és Orbán”, Origo hirportál, 06. 10. 2006. http://www.origo.hu/itthon/20061005gyava.html (Downloaded: 21. 02. 2012.)

Girst, Noémi - András Keil (2011), “Zavar a fejekben? A magyarországi elit és a politika 2009-ben”, in: Imre Kovách ed., Elitek a válság korában, Budapest, Argumentum, pp. 315-336.

Hetherington, Marc J. (2001), "Resurgent Mass Partisanship: The Role of Elite Polarization", American Political Science Review Vol. 95, No. 3, pp. 619-631.

Higley, John - György Lengyel (2000), "Introduction: Elite Configurations after State Socialism", in Higley, John - György Lengyel, eds., Elites under State Socialism: Theories and Analysis, Lanham, MD, Rowman and Littlefield. pp. 1-20.

Higley, John - Michael Burton (2006), Elite Foundations of Liberal Democracy, Lanham, MD, Rowman \& Littlefield

Higley, John - Jan Pakulski - Wlodzimierz Wesolowski (2002), "Introduction: Elite Change and Democratic Regimes in Eastern Europe", in: Higley, John - Jan Pakulski - Wlodzimierz Wesolowski eds., Postcommunist Elites and Democracy in Eastern Europe, Chippenham, Wiltshire, Palgrave, pp. 1-33.

Hindmoor, Andrew (2004), New Labour at the Centre: Constructing Political Space, Oxford and New York, Oxford University Press

Ilonszki, Gabriella - György Lengyel (2010), "Hungary: Between Consolidated and Simulated Democracy”, in Best, Heinrich - John Higley eds. ,Democratic Elitism: New Theoretical and Comparative Perspectives, Leiden and Boston, Brill, pp. 153172.

Jakab, András (2010), "Mire jó egy alkotmány? A vagy az újonnan előkészülő alkotmány legitimitásának kérdése”, Kommentár No. 6, pp. 10-23.

Karácsony, Gergely (2006), “Árkok és légvárak. A választói viselkedés stabilizálódása Magyarországon”, in: Karácsony, Gergely ed., A 2006-os országgyülési választások. Elemzések és adatok, Budapest, DKMKA, pp. 59-103.

King, David C. (1997), "The Polarization of American Parties and Mistrust of Government", in: Nye, Joseph S. - Jr., Philip D. Zelikow - David C. King, eds., Why People Don't Trust Government, Cambridge, Mass. and London, Harvard University Press, pp. 155-178.

Kitschelt, Herbert - Zdenka Mansfeldova - Radoslaw Markowski - Gábor Tóka 
(1999), Post-Communist Party Systems: Competition, Representation, and InterParty Competition, Cambridge, Cambridge University Press

Kitschelt, Herbert (1992), "The Formation of Party Systems in East Central Europe", Politics and Society Vol. 20, No. 1, pp. 7-50.

Kitschelt, Herbert (1994), The Transformation of European Social Democracy, Cambridge, Cambridge University Press

Kitschelt, Herbert (1995), The Radical Right in Western Europe, Ann Arbor, University of Michigan Press

Körösényi, András (1999), Government and Politics in Hungary, Budapest, Central European University, Press-Osiris, pp.1-330.

Körösényi, András (2001), "Parlamentáris vagy "elnöki” kormányzás? Az Orbánkormány összehasonlító perspektívából”, Századvég No. 20, pp. 3-38.

Körösényi, András (2007), "Legitimacy of the Constitution in Hungary 1985-2005", in Jakab, András - Péter Takács - Allan, F. Tatham, eds., The Transformation of Hungarian Legal Order 1985-2005, The Netherlands, Kluwer Law International, pp. 547-561.

Körösényi, András (2010), "Stuck in Escher's staircase: Leadership, manipulation and democracy", Österreichische Zeitschrift für Politikwissenschaft Vol. 39, No. 3, pp. 289-302.

Kristóf, Luca (2005), “Közéleti értelmiség és hírnév”, Századvég No. 25, pp. 97-127.

Kristóf, Luca (2011), "Politikai nézetek és reputáció az értelmiségi elitben", Politikatudományi Szemle Vol. 20, No. 2., pp. 83-105.

Layman, Geoffry C. - Thomas M. Carsey (2002), "Party Polarization and 'Conflict Extension' int he American Electorate", American Journal of Political Science Vol. 46, No. 4, pp. 786-802.

Levendusky, Matthew S. (2010), "Clearer Cues, More Consistent Voters: A Benefit of Elite Polarization”, Political Behaviour Vol. 32, No.1, pp. 111-131.

McCarty, Nolan (n.d.), The Policy Consequences of Partisan Polarization in the United States, MS, Princeton University

Pakulski, Jan - András Körösényi (2012), Toward Leader Democracy, London-New York-Delhi, Anthem Press

Palonen, Emilia (2009), "Political Polarisation and Populism in Contemporary Hungary", Parliamentary Affairs Vol. 62, No. 2, pp. 318-334.

Plous, Scott (1993), The Psychology of Judgement and Decision Making, New York, McGraw-Hill, Inc

Przeworski, Adam - John Sprague (1986), Paper Stones, Chicago, Chicago University Press

Rae, Douglas W. - Michael Taylor (1970), The analysis of political cleavages, New Haven, Yale University Press

Rokkan, Stein (1999), State Formation, Nation Building, and Mass Politics in Europe. The Theory of Stein Rokkan, ed. by Flora, Peter, Oxford, Oxford University Press

Róbert, Péter - Zsófia Papp (2012), “Kritikus választás? Pártos elkötelezettség és szavazói viselkedés a 2010-es országgyülési választáson”, in: Boda, Zsolt András Körösényi eds., Van Irány? Trendek a magyar politikában, Budapest, Új 
Mandátum Kiadó - MTA TK Politikatudományi Intézet, pp. 41-64.

Sartori, Giovanni (1969), "From the Sociology of Politics to Political Sociology", in Lipset, Seymour M. ed., Politics and the Social Sciences, New York, Oxford University Press, pp. 65-100.

Sartori, Giovanni (1976), Parties and Party Systems, Cambridge, New York, Melbourne, Cambridge University Press

Schmitt, Hermann - Angelika Scheuer (2011), “A választói döntések meghatározói Kelet- és Nyugat-Európában” in: Tardos, Róbert - Zsolt Enyedi - Andrea Szabó eds., Részvétel, képviselet, politikai változás, Budapest, Demokrácia Kutatások Magyar Központja Alapítvány, pp. 315-346.

Schultz, Christian (1996), "Polarization and Inefficient Policies", Review of Economic Studies Vol. 63, pp. 331-344.

Schultz, Christian (2008), "Information, polarization and term length in democracy", Journal of Public Economics Vol. 92, pp. 1078-1091.

Schumpeter, A. Joseph. (1987 /1942/), Capitalism, Socialism and Democracy, London, Unwin

Soós, Gábot (2012), "Kétblokkrendszer magyarországon”, in: Boda, Zsolt - András Körösényi eds., Van Irány? Trendek a magyar politikában, Budapest, Új Mandátum Kiadó - MTA TK Politikatudományi Intézet, pp. 14-40.

Tóka, Gábor (2005), “A törésvonalak, a pártok és az intézményrendszer”, in: Angelusz, Róbert - Róbert Tardos eds., Törések, hálók, hidak. Választói magatartás és politikai tagolódás Magyarországon, Budapest, Demokrácia Kutatások Magyar Központja Alapítvány, pp. 243-321.

Tóka, Gábor (2005a), “A magyarországi politikai tagoltság nemzetközi összehasonlításban", in: Angelusz, Róbert - Róbert Tardos eds., Törések, hálók, hidak. Választói magatartás és politikai tagolódás Magyarországon, Budapest, Demokrácia Kutatások Magyar Központja Alapítvány, pp. 17-64.

Tóka, Gábor (2006), "Vezérek csodálói. A magyar választói magatartás nemzetközi összehasonlításban”, in Karácsony, Gergely ed., Parlamenti választás 2006. Elemzések és adatok, Budapest, Demokrácia Kutatások Magyar Központja Alapítvány - Budapesti Corvinus Egyetem, Politikatudományi Intézet, pp. 17-58.

Zaller, R. John (1992), The Nature and Origins of Mass Opinion, New York, Cambridge University Press

Zuckerman, Alan (1975), "Political Cleavage: A Conceptual and Theoretical Analysis", British Journal of Political Science Vol. No, 2, pp. 231-248. 